\title{
Pertanggungjawaban Kantor Pertanahan atas Kendala Sistem Pemasangan Hak Tanggungan Elektronik
}

\author{
Rizky Amelya Wirasti \\ Magister Kenotariatan Fakultas Hukum Universitas Islam Indonesia Yogyakarta Indonesia \\ Jln. Cik Di Tiro No. 1 Yogyakarta Indonesia \\ rizkyamelya18@gmail.com
}

\begin{tabular}{ll}
\hline Key Word: & Abstract \\
Accountability of & E-government acceleration is also implemented in Mortgage services through the \\
the Land Office, issuance of the Minister of Agrarian Affairs and Spatial Planning/National Land \\
HT-el Constraints, Agency Regulation No. 5 of 2020 on Electronic Mortgage Services. Electronic \\
HT-el \\
$\quad$ Mortgage Rights aim to improve services that meet the principles of openness, \\
timeliness, convenience, and speed. This study examines two problem formulations, \\
namely the responsibility of the land office in the event of problems with the installation \\
of Electronic Mortgage Rights, as well as obstacles that occur in the imposition of \\
Electronic Mortgage Rights. This research is an empirical normative research that aims \\
to see the implementation of normative legal provisions (laws) in action in every \\
particular legal event that occurs in a society. The results of this study conclude that \\
the responsibility of the Land Office is only technical. In addition, the obstacles that \\
occur in the electronic imposition of Mortgage Rights that are often faced by HT-el \\
users and implementers are problems with the IT system (Information Technology) or \\
the HT-el application itself which is often difficult to access.
\end{tabular}

\section{Kata-kata Kunci: \\ HT-el, Kendala HT-el,}

Pertanggungjawaban Kantor Pertanahan

\begin{abstract}
Abstrak
Akselerasi e-government juga diterapkan dalam pelayanan Hak Tanggungan melalui penerbitan Peraturan Meneri Agraria dan Tata Ruang/Badan Pertanahan Nasional Nomor 5 Tahun 2020 tentang pelayanan Hak Tanggungan secara Elektronik. Hak Tanggungan Elektronik bertujuan untuk meningkatkan pelayanan yang memenuhi asas keterbukaan, ketepatan waktu, kemudahan, serta kecepatan Namun dalam pelaksanaan HT-el sering terjadi kendala yang dialami oleh pengguna dan pelaksana HT-el itu sendiri. Penelitian ini mengkaji dua rumusan masalah yakni tanggung jawab kantor pertanahan apabila terjadi kendala pada sistem pemasangan Hak Tanggungan Elektronik, serta kendala yang terjadi dalam pembebanan Hak Tanggungan Elektronik. Penelitian ini merupakan penelitian normatif empiris yang bertujuan untuk melihat implementasi ketentuan hukum normatif (undang-undang) dalam aksinya disetiap peristiwa hukum tertentu yang terjadi dalam suatu masyarakat. Hasil penelitian ini menyimpulkan bahwa pertanggungjawaban kantor Pertanahan hanya secara teknis. Selain itu kendala yang terjadi dalam pembebanan Hak Tanggungan secara elektronik yang sering dihadapi oleh pengguna dan pelaksana HT-el yaitu kendala pada sistem ITnya (Informasi Teknologi) atau aplikasi HT-elnya itu sendiri yang sering susah untuk diakses
\end{abstract}

\section{Pendahuluan}

Pada era industrialisasi saat ini dalam rangka meningkatkan pertumbuhan di bidang ekonomi maka dibutuhkan pendanaan yang cukup besar, sehingga perlu adanya dukungan pihak-pihak yang mampu menyediakan kebutuhan pendanaan tersebut. Salah satu bentuk pendanaan dalam rangka meningkatkan pertumbuhan bidang ekonomi akan melalui pemberian fasilitas kredit yang berasal dari lembanga keuangan bank dan non bank. 
Jika ditinjau dari segi konsep, menurut O.P Simorangkir kredit adalah pemberian prestasi (misalnya uang, barang) dengan balas prestasi (kontra prestasi) akan terjadi pada waktu mendatang. ${ }^{1}$ Kredit didasarkan pada suatu perjanjian kredit yang merupakan perjanjian pendahulu, sedangkan perjanjian hutang piutang merupakan pelaksanaan dari perjanjian pendahulu atau perjanjian kredit. Fasilitas kredit yang dapat diberikan oleh lembaga keuangan bank dan non bank memiliki syarat-syarat khusus yang harus dipenuhi oleh calon debitur. Adapun salah satu bentuk persyarakat khusus tersebut adalah adanya suatu jaminan. Jaminan yang diberikankan oleh debitur kepada kreditur dalam perjanjian kredit merupakan perjanjian acessoir yaitu perjanjian tambahan yang mengikuti perjanjian pokoknya.

Jaminan secara umum diatur dalam Pasal 1131 KUHPerdata yang menetapkan bahwa segala hak kebendaan debitur baik yang bergerak maupun yang tidak bergerak, baik yang sudah ada maupun yang akan ada di kemudian hari menjadi tanggungan untuk segala perikatannya. Sehubungan dengan adanya upaya untuk menjamin atas pengembalian dana kredit dari lembaga pemberi kredit, maka sangat dibutuhkan lembaga jaminan yang kuat dan mampu memberi kepastian hukum bagi pihak-pihak yang berkepentingan. Adanya lembaga jaminan tersebut dapat meningkatkan kepercayaan lembaga keuangan bank dan non bank untuk menyalurkan dana kredit kepada pihak yang membutuhkan. Salah satu jenis lembaga penjaminan yang dikenal di Indonesia adalah lembaga Hak Tanggungan. Hak Tanggungan diharapkan mampu menjadi lembaga jaminan yang kuat dan dapat memberikan kepastian hukum. "Hak Tanggungan sebagai lembaga jaminan yang kuat mempunyai droit de preference (mempunyai kedudukan diutamakan bagi pemegangnya) dan droit de suite (mengikuti objek Hak Tanggungan di tangan siapa pun objek itu berada) sebagai ciri-cirinya" .2

Proses pembebanan Hak Tanggungan dilaksanakan melalui 2 tahap kegiatan, yaitu:

a. Tahap pemberian Hak Tanggungan, yang dilakukan dihadapan Pejabat Pembuat Akta Tanah (PPAT) yang didahului dengan perjanjian utang-piutang yang dijamin.

b. Tahap pendaftarannya oleh Kantor Pertanahan yang merupakan saat lahirnya Hak Tanggungan yang dibebankan. ${ }^{3}$

Akibat dari pesatnya akselerasi penggunaan teknologi informasi di bidang Pemerintahan (e-governance) juga memberikan dampak dalam perkembangan Hak Tanggungan di Indonesia. Pemerintah menyediakan layanan Pendaftaran Hak Tanggungan yang terintegrasi secara elektronik yang diatur dalam Peraturan Menteri Agraria dan Tata Ruang/Badan Pertanahan Nasional Nomor 5 Tahun 2020 tentang Pelayanan Hak Tanggungan Secara Elektronik yang diundangkan sejak 8 April 2020 dan dilaksanakan secara serentak pada 8 juli 2020 di seluruh Kantor Pertanahan. Hak Tanggungan elektronik yang sering disingkat dengan HT-el ini bertujuan untuk meningkatkan pelayanan yang memenuhi asas keterbukaan, ketepatan waktu, kecepatan,

${ }^{1}$ O.P Simorangkir, Seluk Beluk Bank Komersial, Cetakan Kelima, Aksara Persada Indonesia, Jakarta, 1998, hlm. 91

2 Purawahid Patrik dan Kashadi, Hukum Jaminan, Badan Penerbit Universitas Diponegoro, Semarang, 2009, hlm. 109.

${ }^{3}$ Habib Adjie, Hak Tanggungan Sebagai Lembaga Jaminan Atas Tanah, Mandar Maju, Bandung, 2000, hlm. 8 
kemudahan, serta dapat lebih mempermudah dan mempercepat masyarakat dan PPAT dalam pelayanan dibanding dengan layanan konvensional.

Terdapat perbedaan tata cara pelaksanaan pendaftaran Hak Tanggungan dari segi peraturannya dan dari segi mekanismenya. Dari segi peraturannya pendaftaran Hak Tanggungan secara konvensional dijelaskan dalam Pasal 13 dan 14 Undang-Undang Nomor 4 Tahun 1996 tentang Hak Tanggungan atas Tanah Beserta Benda-Benda yang Berkaitan dengan Tanah (selanjutnya disebut dengan UU Hak Tanggungan). Sedangkan pada Hak Tangungan Elektronik dijelaskan dalam Pasal 9 dan 10 Permen ATR/BPN No. 5 Tahun 2020. Secara mekanisme pelaksanaannya Hak Tanggungan secara konvensional dilakukan dengan pemberian kuasa oleh Bank kepada PPAT secara penuh dalam pengurusan pendaftaran Hak Tanggungan tersebut. PPAT harus datang langsung ke kantor pertanahan guna menyampaikan berkas-berkas yang diperlukan. Sedangkan HTel PPAT wajib menggunakan aplikasi yang disediakan kementrian ATR/BPN dengan menjadi mitra kerja BPN begitu juga dengan bank. PPAT dan Bank diharuskan mendaftar dan membuat akun terlebih dahulu secara online. melalui portal mitra kerja di browser dengan alamat: https://mitra.atrbpn.go.id/datappat/login/, kemudian menyerahkan salinan akta dan sertipikat Tanah kepada Bank, sedangkan Bank membuat berkas permohonan secara elektronik (tanpa perlu datang ke BPN), membayar biaya pendaftaran, menerima sertipikat HT-el pada hari ke tujuh, produk sertipikat HT berupa file PDF dengan tanda tangan digital. Selanjutnya, Kreditor mencetak dan melekatkan catatan pendaftaran pada sertipikat Hak Atas Tanah yang menjadi objek jaminan. Jika tidak melakukan pemutakhiran data maka tidak dapat mengakses dan mendaftarkan layanan pada aplikasi pelayanan pertanahan secara elektronik. Sehingga PPAT tidak dapat menjadi pengguna dalam pelayanan HT-el tersebut.

Diberlakukannya HT-el ini memberikan keuntungan bagi pengguna antara lain pengurusan HT-el menjadi lebih praktis dan efisien. Hal tersebut dikarenakan penggurusan HT-el tidak dilakukan secara face to face, maka dapat untuk meminimalisir dan menghindari adanya kegiatan non hukum seperti korupsi, kolusi, dan nepotisme.

Di dalam prakteknya pelaksanaan pelayanan HT-el tidak selalu berjalan dengan lancar, karena HT-el merupakan sesuatu hal yang tergolong baru serta pemberlakuan pelaksanaannya dilakukan tanpa melalui transisi sosialisasi yang memadahi mengakibatkan banyak kendala yang muncul dalam pelaksanaan pelayanan HT-el. Adanya kendala yang muncul dalam pendaftaran HT-el khususnya bagi pengguna HT-el yaitu PPAT dan kreditor perlu adanya penyelesaian. Oleh karena itu perlu, dikaji terkait denan pertanggungjawaban Kantor Pertanahan apabila terjadi kendala sistem dalam rangka pemasangan HT-el agar tidak merugikan masyarakat.

\section{Rumusan Masalah}

Rumusan masalah yang menjadi fokus pengkajian dalam penelitian ini, pertama, bagaimana tanggung jawab kantor pertanahan apabila terjadi kendala pada sistem pemasangan Hak Tanggungan Elektronik? Kedua, apa saja kendala yang terjadi dalam pembebanan Hak Tanggungan Elektronik? 


\section{Tujuan Penelitian}

Penelitian ini bertujuan untuk mengetahui pertama, mengenai tanggung jawab kantor pertanahan apabila terjadi kendala pada sistem pemasangan Hak Tanggungan Elektronik. Kedua, kendala yang terjadi dalam pendaftaran Hak Tanggungan Elektronik.

\section{Metode Penelitian}

Metode penelitian yang akan digunakan dalam penulisan hukum ini adalah normatif metode yang menggabungkan unsur hukum normatif yang kemudian didukung dengan penambahan data atau unsur empiris yang berfungsi untuk melihat implementasi ketentuan hukum normatif (undang-undang) dalam aksinya disetiap peristiwa hukum tertentu yang terjadi dalam suatu masyarakat.

\section{Hasil Penelitian dan Pembahasan}

\section{Tanggungjawab Kantor Pertanahan Apabila Terjadi Kendala pada Sistem dalam Pemasangan Hak Tanggungan Elektronik}

Berkaitan dengan pendaftaran jaminan Hak Tangungan pada 21 Juni 2019 pemerintah melalui Menteri ATR/BPN menerbitkan Peraturan Menteri ATR/BPN Nomor 9 Tahun 2019 tentang Pelayanan Hak Tanggungan Terintegrasi Secara Elektronik. Merujuk pada Pasal 1 ayat (7) Peraturan Menteri ATR/BPN Nomor 5 Tahun 2020 bahwa Pelayanan Hak Tanggungan Terintegrasi Secara Elektronik yang selanjutnya disebut Pelayanan HT-el adalah serangkaian proses pelayanan hak tanggungan dalam rangka pemeliharaan data pendaftaran tanah yang diselenggarakan melalui sistem elektronik yang terintegrasi.

Hal ini sebagai perwujudan dari Peraturan Pemerintah Nomor 82 Tahun 2012 tentang Penyelenggaraan Sistem dan Transaksi Elektronik. Sistem elektronik berdasarkan Pasal 1 ayat (1) Peraturan Pemerintah Nomor 82 Tahun 2012 tentang Penyelenggaraan Sistem dan Transaksi Elektronik adalah serangkaian perangkat dan prosedur elektronik yang berfungsi mempersiapkan, mengumpulkan, mengolah, menganalisis, menyimpan, menampilkan, mengumumkan, mengirimkan, dan/atau menyebarkan Informasi Elektronik. Namun peraturan ini hanya berjalan satu tahun, pada 8 Juli 2020 Peraturan Menteri ATR/BPN Nomor 9 Tahun 2019 dicabut dan diganti dengan Peraturan Menteri ATR/BPN Nomor 5 Tahun 2020 Tentang Pelayanan Hak Tanggungan Terintegrasi Secara Elektronik yang berdasarkan Pasal 38 Peraturan Menteri ini mulai berlaku pada tanggal diundangkan yakni 8 April 2020. Dengan diterbitkannya Peraturan Menteri tersebut merupakan langkah maju Kementerian ATR/BPN dalam mempermudah masyarakat untuk mendapatkan pelayanan dari kementerian tersebut dengan memanfaatkan perkembangan teknologi. ${ }^{4}$

Proses pembebanan Hak Tanggungan secara elektronik sejak pembuatan Akta Pemberian Hak Tanggungan (APHT) sampai terbitnya Sertifikat Hak Tanggungan dapat dilihat pada gambar alur/proses pembebanan HT-el di bawah ini:

4 http://pusdiknas.com/workshop-nasional/, Kebijakan Dan Implementasi Hak Tanggungan Terintegrasi Secara Elektronik Berdasakan Permen Atr No. 9 Tabun 2019, diakses pada tanggal 23 Oktober 2021 


\section{LAYANAN HAK TANGGUNGAN ELEKTRONIK}

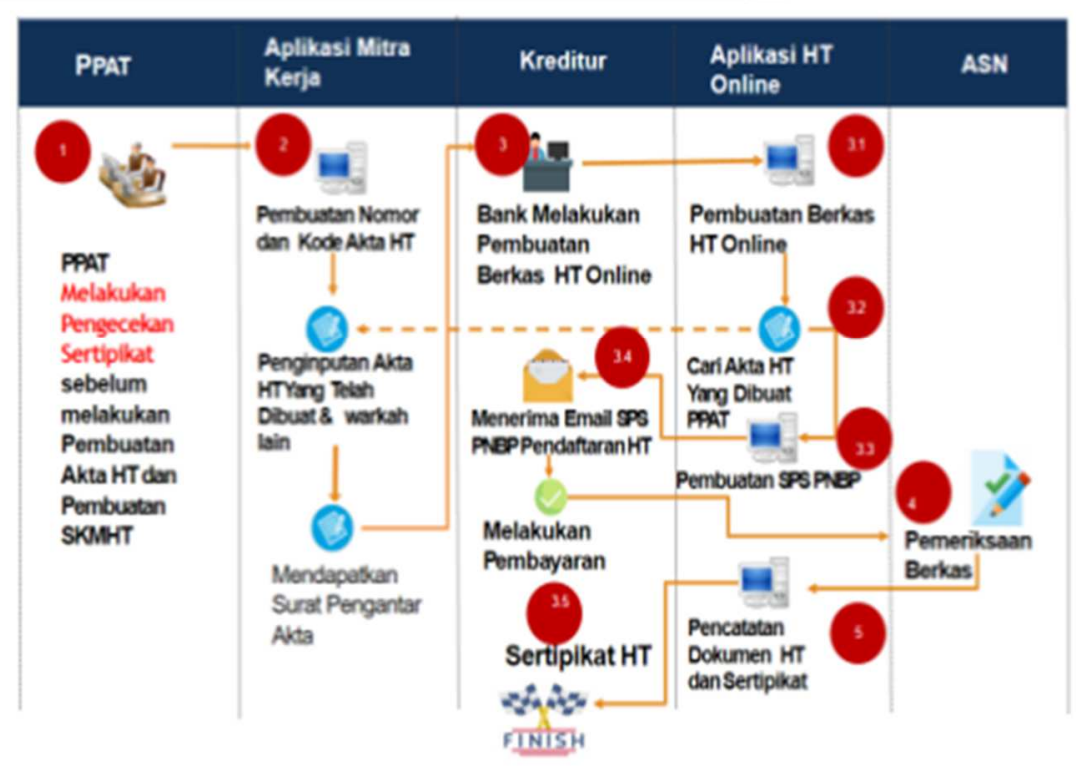

Gambar 1. Layanan Hak Tanggungan Elektronik

Bagi PPAT sebelum melakukan proses pendaftaran Hak Tanggungan harus mendaftar terlebih dahulu pada Aplikasi Mitra Kerja PPAT pada mitra.atrbpn.go.id dan sudah melakukan validasi data serta telah diverifikasi oleh Kantor Pertanahan. Alur atau mekanisme pendaftaran HT-el dilakukan dari aplikasi https://htel.atrbpn.go.id oleh user yang terdaftar sebagai PPAT dan Jasa Keuangan. Setelah login ke aplikasi mitra BPN kemudain tahapan-tahapan yang dilakukan yaitu ${ }^{5}$

1. Pihak kreditur/bank datang ke PPAT untuk dibuatkan APHT;

2. Melakukan pengecekan sertifikat/surat ukur objek jaminan Hak Tanggungan secara manual dan di cek ke sistem elektronik;

3. setelah pengecekan dan hasilnya sesuai maka akan dibuatkan APHT (Akta Pemberian Hak Tanggungan) dan di tandatangani oleh bank kemudian kembali lagi ke PPAT;

4. APHT yang sudah ditandatangani kemudian di scan dan diinput ke dalam sistem bersamaan dengan dokumen-dokumen lain, seperti KTP, sertifikat objek jaminan HT, PNBP, Kuasa bank, SKMHT (jika dasarnya dari SKMHT), kedalam sistem HT-el;

5. Setelah itu download surat pengantar akta dan diserahkan kepihak kreditur/Bank.

Alur Mekanisme Hak Tanggungan Elektronik oleh Bank selaku kreditur: ${ }^{6}$

1. Bank login ke aplikasi HT Elektronik;

2. Bank melakukan pembuatan berkas pemohonan HT online yang di tandatangani oleh pimpinan dan bermaterai cukup kemudian di scan dan di uplad pada aplikasi bersama akta HT yang telah dibuat oleh PPAT;

${ }^{5}$ Wawancara PPAT Kabupaten Bantul Anindita, S.H., M.Kn. di kantor Notaris dan PPAT Anindita, pada 5 Juli 2021.

${ }^{6}$ Wawancara Petugas Hak Tanggungan Bank BRI cabang bantul pada 23 Agustus 2021 
3. Kemudian akan muncul SPS (Surat Perintah Setor) PNPB dan lakukan pembayaran.

4. Setelah 7 hari mencetak sertifikat HT dan melekatkan catatan HT.

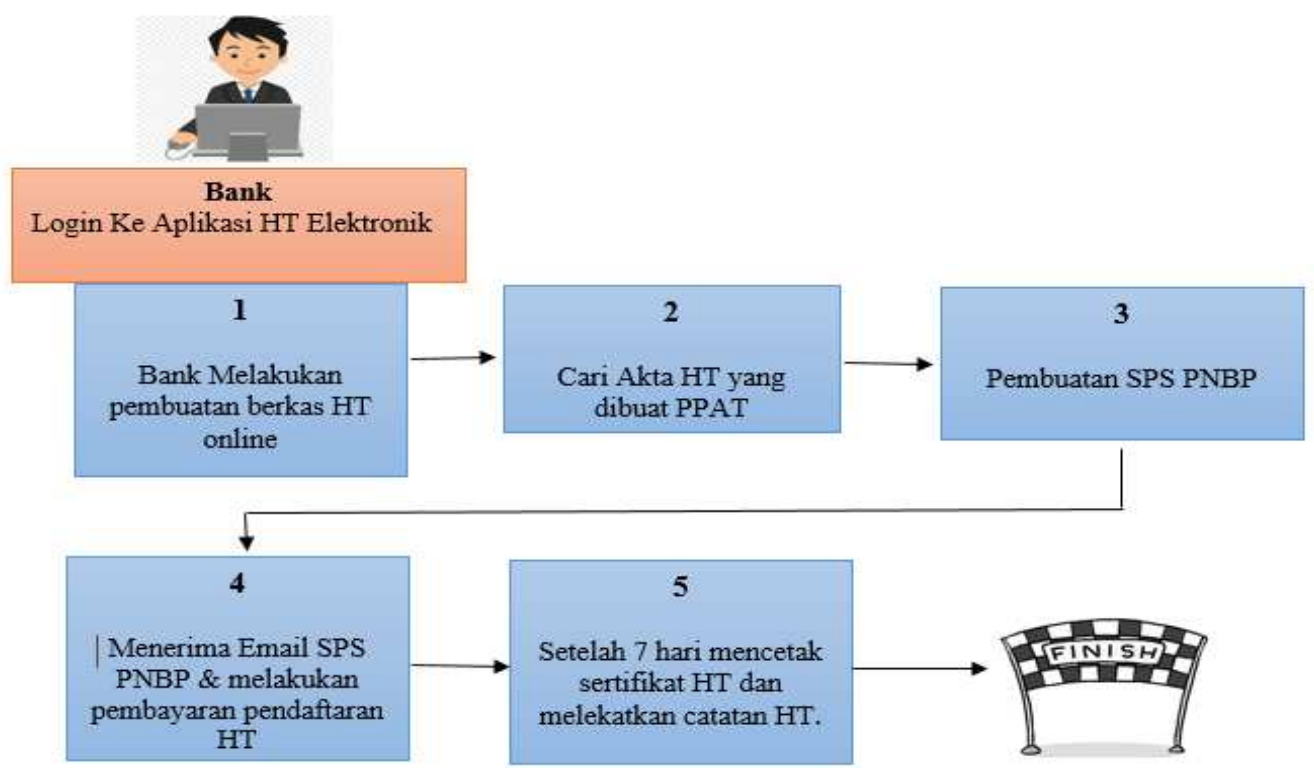

Gambar 2. Alur Mekanisme Hak Tanggungan Elektronik oleh Bank

Sertipikat HT-el bisa di download dan dicetak oleh kreditur, sertipikat ini hanya satu lembar dan dalam bentuk pdf, di dalam sertipikat HT-el terdapat barcode yang berisi seluruh informasi terkait Sertifikat Hak Tanggungan tersebut yang dapat digunakan untuk mengecek hasil layanan dengan melakukan scan menggunakan aplikasi Sentuh Tanahku. Dengan diberlakukannya sistem HT-el sangatlah memberikan keuntungan besar bagi PPAT dan Kreditur itu sendiri keuntungan- keuntungan lainnya antara lain:

1. Lebih efisien, menyingkat waktu, serta adanya ketepatan waktu pendaftaran Hak Tanggungan .

2. Karena tidak dilakukan secara face to face (tatap muka) maka sangat meminimalisir terjadinya tindakan korupsi, kolusi dan nepotisme.

3. Adanya monitoring pengerjaan pendaftaran Hak Tanggungan, sehingga Bank dan PPAT dapat saling memantau letak progress pengerjaan Hak Tanggungan serta adanya dual control antara PPAT dan Bank tekait transparasi proses pengerjaannya.

Di samping banyaknya kelebihan dalam pelayanan pendaftaran Hak Tanggungan secara elektronik terdapat pula kendala yang sering terjadi di dalam sistem (Informasi Tekhnologi) atau aplikasi HT-el itu sendiri. Apabila terjadi kendala yang disebabkan oleh sistem IT atau aplikasi HT-el nya, maka kantor pertanahan akan memberikan solusi secara tekhnis dengan bagian sistem IT pelayanan HT-el melalui aplikasi Whatsaap atau datang langsung ke Kantor Pertanahan setempat sesuai jadwal yang sudah ditentukan oleh Kantor Pertanahan.

Undang-Undang Hak Tanggungan dan Peraturan Menteri ATR/BPN Nomor 5 Tahun 2020 tidak mengatur secara tegas mengenai pertanggungjawaban dan sanksi bagi 
Kantor Pertanahan apabila terjadi kendala pada sistem dalam pendaftaran HT-el yang mengakibatkan sertipikat HT tidak dapat terbit.

Setelah lahirnya Peraturan Menteri ATR/BPN Nomor 5 Tahun 2020 untuk petunjuk tekhnis pelaksanaan pendaftaran HT-el Kantor Pertanahan mengeluarkan Petunjuk Tekhnis Nomor: 2/Juknis-400.HR.02/IV/2020 yang menjadi acuan atau pedoman bagi Kantor Pertanahan dalam melaksanakan pelayanan HT-el. Di dalam Petunjuk Tekhnis tersebut kendala sistem pada HT-el termasuk dalam kategori force majeur, apabila terjadi kendala dalam sistem yang menyebabkan Sistem HT-el terganggu sehingga mengakibatkan hasil layanan Hak Tanggungan tidak dapat diterbitkan dan permohonan Pelayanan HT-el dinyatakan batal pemohon dapat mengajukan permohonan pendaftaran ulang, serta dapat mengajukan permohonan pengembalian biaya layanan. Namun, pada kenyataannya batalnya penerbitan HT-el yang dikarenakan adanya kendala pada sistemn HT-el mengakibatkan kerugian bagi PPAT dan kreditur dikarenakan PPAT dan kreditur harus mengulang proses HT-el dari awal hal tersebut sangatlah membuang-buang waktu dan biaya pelayanan serta Pendapatan Negara Bukan Pajak (PNBP) yang sudah dibayarkan sebelumnya menjadi hangus dan harus membayar ulang, meskipun sudah ada petunjuk tekhnis mengenai pengembalian biaya namun dalam praktek dilapangan prosesnya sangatlah sulit.

Di dalam Petunjuk Tekhnis Nomor: 2/Juknis-400.HR.02/IV/2020 juga menyebutkan apabila terdapat permasalahan yang tidak dapat diselesaikan di tingkat Kantor Wilayah Badan Pertanahan Nasional, maka Tim Pembina dan Pengawas Pelaksanaan Pelayanan Hak Tanggungan Terintegrasi Secara Elektronik di Kantor Wilayah Badan Pertanahan Nasional berkoordinasi dengan tim di tingkat Kementerian untuk mendapat alternatif penyelesaian. Dengan kata lain, selama ini Kantor Pertanahan dalam memberikan pertanggungjawaban yang diakibatkan karena kendala sistem pada HT-el hanya secara tekhnis saja yaitu dengan memberikan solusi kepada PPAT maupun Bank selaku kreditur untuk dapat berkominukasi secara langsung kepada pegawai Kantor Pertanahan setempat bagian pelayanan pendaftaran Hak Tanggungan Elektronik melalui aplikasi Whatsaap dan bisa juga datang langsung ke kantor pertanahan mengahadap bagian IT pelayanan Hak Tanggungan Elektronik dengan jadwal yang sudah ditentukan oleh Kantor Pertanahan, dan apabila terdapat permasalahan yang masih bisa diselesaikan melalui aplikasi Kantor Pertanahan akan menyelesaikan permasalahan tersebut melalui sistem HT-el yang kemudian pemberitahuan akan terkirim secara otomatis ke email PPAT maupun Bank.

\section{Kendala yang Terjadi dalam Pembebanan Hak Tanggungan Elektronik}

Penyelenggaraan pelayanan Hak Tanggungan Elektronik tidaklah selalu berjalan dengan lancar, dapat dilihat di dalam pembahasan sebelumnya bahwa kendala utama yang sering dialami oleh pengguna sistem HT-el yaitu PPAT dan Bank selaku kreditur serta Kantor Pertanahan selaku penyelenggara ialah mengenai sistem HT-el atau aplikasi HT-el yang masih sering bermasalah. Terdapat bula beberapa kendala yang dialami oleh PPAT dan Bank selaku kreditur serta Kantor Pertanahan sebagai pelaksana HT-el antara lain PPAT: 
a. Kendala pada PPAT yakni: 1). Pengkoreksian yang dilakukan oleh Kantor Pertanahan terhadap berkas yang telah di upload oleh PPAT sering terjadi dalam waktu yang mepet padahal belum tentu berkas yang harus dibenarkan merupakan berkas yang mudah didapat, hal tersebut menyebabkan SPS PNBP dan biaya layanan hangus dan Kantor Pertanahan tidak mau disalahkan sehingga mengakibatkan kerugian pada kreditur. 2). Aplikasi HT sering mengalami masalah atau server erorr yang biasanya terjadi pada jam kerja, hal tersebut terjadi karena sistem IT atau sistem HT-el yang belum siap. 3). Data fisik di dalam Sertifikat tidak sama dengan data yang ada di Kantor Pertanahan, Sertifikat belum siap ketika mau di upload, belum tervalidasi, belum terploating. 5) Bank selaku kreditur perlu selalu diingatkan untuk segera melakukan proses pendaftaran Hak Tanggungan karena Bank biasanya lama dalam melakukan hal tersebut maka diperlukan komunikasi yang baik antara PPAT dan Bank selaku kreditur.

b. Kendala pada Bank selaku Kreditur yaitu: 1). Sistem mitra pada HT el sering tidak nyambung karena digunakan di seluruh Indonesia pada jam kerja, maka sering terjadi server erorr. 2). Pada saat proses roya sering terjadi ketidak sesuaian catatan roya yang tertera pada Sertifikat fisik dengan data di Kantor Pertanahan, di Sertifikat Hak Milik sudah tertera catatan roya nya tetapi ketika akan di entry ke dalam sistem elektronik atau online proses roya tersebut tidak terditeksi 3). Karena belum siapnya sistem IT pada HT-el dalam proses roya banyak proses yang tidak dapat dikerjakan melalui komputer dan harus menggunakan handphone terlebih dahulu kemudian baru dilanjutkan menggunakan komputer.

c. Kendala pada Kantor Pertanahan selaku pelaksana HT-el yaitu: 1). sebelum adanya perbaikan sistem kendala utama yang dialami oleh Kantor Pertanahan yaitu terjadi pada server pusat yang koneksinya sering mengalami permasalahan karena digunakan oleh seluruh Indonesia pada jam dan hari yang bersamaan, maka koneksinya menjadi lambat.

d. Kendala pada Kreditur perorangan: 1) ketidakpahaman dalam mendaftar pada aplikasi sentuh tanahku yang merupakan aplikasi HT-el bagi kreditur perorangan dikarenakan tidak semua kreditur perorangan paham dengan hukum dan sistem IT.

\section{Penutup}

Dari pembahasan di atas dapat disimpulkan pertama bahwa Undang-Undang Hak Tanggungan dan Peraturan Menteri ATR/BPN Nomor 5 Tahun 2020 tidak mengatur secara tegas mengenai pertanggungjawaban dan sanksi bagi Kantor Pertanahan apabila terjadi kendala pada sistem dalam pemasangan HT-el yang mengakibatkan sertipikat HT-el batal dan tidak dapat terbit. Setelah diterbitkan Petunjuk Tekhnis Nomor: 2/Juknis-400.HR.02/IV/2020, Kantor Pertanahan dalam melaksanan pelayanan HT-el mengacu dan berpedoman kepada Petunjuk Tekhnis tersebut, pertanggungjawaban Kantor Pertanahan apabila terjadi kendala pada sistem IT atau aplikasi HT-el hanya pertanggungjawaban secara teknis dengan memberikan akses kepada PPAT/Bank selaku kreditur untuk berkominukasi secara langsung kepada pegawai Kantor Pertanahan bagian pelayanan pendaftaran Hak Tanggungan Elektronik dan apabila terdapat 
permasalahan yang masih bisa diselesaikan melalui aplikasi HT-el maka Kantor Pertanahan akan menyelesaikan permasalahan tersebut melalui aplikasi HT-el yang otomatis notification atau pemberitahuannya akan masuk ke e-mail PPAT dan kreditur.

Kedua, bahwa kendala utama yang sering dialami oleh pengguna dan penyelenggara HT-el ialah sistem IT pada HT-el atau aplikasi HT-el yang masih sering bermasalah dan juga perbedaan data antara data pada sertipikat fisik dengan data yang ada dalam sistem HT-el yang dikarenakan belum adanya pembaharuan data oleh Kantor Pertanahan.

Saran yang dapat penulis sampaikan untuk pelaksana HT-el perlunya revisi mengenai peraturan perundang-udangan yang belum ada pengaturan mengenai pertanggungjawaban serta sanksi bagi pengguna serta pelaksana sistem HT-el, menumbuhkan itikad baik dan prinsip mau dan mampu bagi pegawai kantor pertanahan. Karena IT hanyalah sarana bukan ahli hokum, maka dari itu harus menunjang pelaksanaan hukum yang memadai kalau sekiranya tidak menunjang dan tidak maksimal sebaiknya kembali lagi ke konvensional serta secara tekhnis perlu dilakukan validasi secara terus menerus dan pengecekan sertipikat sebaiknya diubah ke Sistem Elektronik untuk memperlancar pelaksanaan HT-el. Saran untuk pengguna HT-el PPAT/Bank hendaklah selalu meng-update ilmu, tekhnologi, dan wawasan, jangan hanya menggunakan prinsip kebiasaan yang jadinya akan tertinggal, PPAT dan kreditur haruslah kompak, bekerja sama, berkomunikasi dengan baik, dan mengkonfirmasi apabila terjadi problem sistem IT kepada penyelenggara layanan HT-el yaitu Kantor Pertanahan setempat. PPAT dan Bank sebagai kreditur hendaklah berusaha untuk lebih memahami mekanisme dan prosedur dari HT-el dengan berpedoman pada Permen ATR/BPN No. 5 Tahun 2020 dan Petunjuk Teknis HT-el No.2 Tahun 2020 untuk meminimalisir kesalahan prosedur dan teknis dalam pelayanan HT-el sehingga penyelenggaraan HT-el dapat berjalan dengan baik, serta output -outcome yang dihasilkan dapat maksimal.

\section{Daftar Pustaka}

\section{Buku}

Adjie, Habib, Hak Tanggungan Sebagai Lembaga Jaminan Atas Tanah, Mandar Maju, Bandung, 2000.

Patrik, Purawahid dan Kashadi, Hukum Jaminan, Badan Penerbit Universitas Diponegoro, Semarang, 2009.

Simorangkir, O.P., Seluk Beluk Bank Komersial, Cetakan Kelima, Aksara Persada Indonesia, Jakarta, 1998.

\section{Internet}

http:/ / pusdiknas.com/workshop-nasional/, Kebijakan Dan Implementasi Hak Tanggungan

Terintegrasi Secara Elektronik Berdasakan Permen Atr No. 9 Tahun 2019

https://docs.atrbpn.go.id/htel/bank/htel/

\section{Peraturan Perundang-Undangan}

Undang-Undang Republik Indonesia No. 4 Tahun 1996 tentang Hak Tanggungan Beserta Benda-Benda Yang Berkaitan Dengan Tanah 
ISSN: 2776-5458 EISSN: 2808-2613

Rizky Amelya Wirasti. Pertanggungjawaban Kantor Pertanahan... 379

Peraturan Menteri Agraria Dan Tata Ruang/Kepala Badan Pertanahan Nasional Republik Indonesia Nomor 5 Tahun 2020 tentang Pelayanan Hak Tanggungan Terintegrasi Secara Elektronik

Petunjuk Tekhnis Menteri Agraria dan Tata Ruang/ Kepala Badan Pertanahan Nasional Nomor: 2/Juknis-400.HR.02/IV/2020 